\title{
HEALTH EDUCATION TERHADAP PENGETAHUANIBU TENTANG PERAWATAN BAYI BERAT LAHIR RENDAH DI RUANG TERATAI RSUD DR.HARJONO PONOROGO
}

\author{
Catur Wulandari \\ Akbid Harapan Mulya Ponorogo \\ Email: cawulan8@gmail.com
}

\begin{abstract}
Low birth weight babies (BBLR) is still a problem worldwide because it is a cause of morbidity and mortality in the newborn, especially during the perinatal period. $L B W$ care is good and true will improve the quality of life $L B W$ so avoid the risk of growth and developmental disorders and death. The purpose of the study to determine the effect of health education on mother's knowledge about the care of Low Birth Weight Baby in Teratai Room Dr.Harjono Ponorogo Hospital.

Pre-experimental research design with One Group Pretest-Posttest approach. The study was conducted 1-31 December 2018. The population is all mothers with Low Birth Weight Infants in Teratai Room Dr. Harjono Ponorogo a total of 37 people and a sample of 31 people, with accidental sampling The independent variable is health education and the dependent variable is knowledge. Instruments with quesionare. Statistical test using wilcoxon signed rank test with $\alpha=0.05$.

The result of knowledge before health education is mostly 16 respondents $(51,6 \%)$ enough and after health education mostly 18 respondents $(58,1 \%)$ good knowledge, $p$ value $0,000 \leq \alpha 0,05$ there is influence of health education to mother knowledge about care of Low Birth Weight Infant in Teratai room of RSUD Dr.Harjono Ponorogo.

Nurses can improve the quality and quantity of health education activities in Lotus room so that the knowledge of mother be good and can do care of Low Birth Weight at home.
\end{abstract}

\section{Keywords: health education, mother knowledge, Low Birth Weight}

\section{PENDAHULUAN}

Bayi berat lahir rendah adalah bayi dengan berat lahir kurang dari 2.500 gram tanpa memandang masa gestasi (Sayekti, 2015). Bayi berat lahir rendah (BBLR) hingga saat ini masih merupakan masalah diseluruh dunia karena merupakan penyebab kesakitan dan kematian pada masa bayi baru lahir khususnya pada masa perinatal (Roeslani, 2016).

BBLR memiliki resiko yang lebih tinggi untuk terkena depresi,hiperaktif, obesitas, hipertensi, diabetes dan gagal jantung sehingga membutuhkan biaya perawatan yang tinggi (Lulakamal, 2016).

Perawatan BBLR adalah usaha yang dilakukan oleh tenaga kesehatan, ibu bayi dan keluarga dalam rangka mempertahankan kelangsungan hidup BBLR (Sayekti, 2015). Orang tua harus mempunyai kemauan yang keras dan mengetahui perawatan BBLR karena setelah pulang dari tempat melahirkan bayi akan dirawat oleh orang tua. Perawatan BBLR yang baik dan benar akan meningkatkan kualitas hidup BBLR sehingga terhindar dari resiko gangguan pertumbuhan dan perkembangan maupun kematian (Judarwanto, 2009).

Berdasarkan Hasil wawancara pada tanggal 16-17 September 2018 terhadap 7 ibu dengan BBLR didapatkan 6 ibu belum mengetahui tentang cara pencegahan kedinginan pada bayi, pemberian ASI yang cukup, cuci tangan sebelum dan sesudah memegang bayi untuk mencegah infeksi. Health 
education tentang perawatan BBLR yang dilakukan di ruang Teratai secara berkelompok belum pernah dilakukan, kegiatan penyuluhan secara individu sudah dilakukan tetapi belum terstruktur. Sebagian besar ibu mengatakan takut merawat bayinya karena bayinya tampak kecil dan lemah.

Berat badan lahir rendah masih menjadi masalah di dunia, kurang lebih $15 \%$ dari bayi lahir hidup adalah BBLR (Roeslani, 2016). Setiap tahun didunia menurut perkiraan World Hearth Organization (WHO), terdapat 5 juta kematian neonatus setiap tahun dengan angka mortalitas neonatus (kematian dalam 28 hari pertama kehidupan) adalah 34 per 1000 kelahiran hidup, dan 98\% kematian tersebut berasal dari Negara berkembang. Secara khusus angka kematian neonatus di asia tenggara adalah 39 per 1000 kelahiran hidup. Angka kejadian di Indonesia sangat bervariasi antara satu daerah dengan daerah lain, yaitu kisaran antara 9\%-30\%, hasil studi di 7 daerah multicenter diperoleh angka BBLR dengan rentang 2,1\%-17,2\%. Secara nasional berdasarkan analisa lanjut SDKI, angka BBLR sekitar 7,5\%. Angka ini lebih besar dari target BBLR yang ditetapkan pada sasaran program perbaikan gizi menuju Indonesia sehat 2010 yakni maksimal 7\% (Proverawati, 2010).

BBLR di Jawa Timur masih menjadi penyebab kematian neonatal tertinggi pada tahun 2010 sebesar $34,72 \%$ dan 2012 sebesar 38,03\%. Resiko kematian BBLR 10 kali lipat dibanding bayi normal. Resiko akan semakin bertambah jika bayi semakin kecil dan imatur (Dinkes Jatim, 2012). Data Jumlah BBLR di ruang Teratai (Perinatologi) RSUD Dr. Harjono Ponorogo pada tahun 2015 sejumlah 298 bayi. Bayi BBLR periode Februari sampai dengan September 2016 di sejumlah 257 bayi, rata-rata tiap bulan 37 bayi.
Menurut Notoatmodjo (2003), pengetahuan (knowledge) merupakan hasil dari tahu, dan ini terjadi setelah orang melakukan penginderaan terhadap suatu objek tertentu. Faktor-faktor yang mempengaruhi pengetahuan seseorang yaitu: 1) pendidikan, 2) pengalaman, 3) usia, 4) pekerjaan, 5) sosial ekonomi, 6) inforrmasi, 7) sosial budaya, dan 8) Lingkungan. Pengetahuan atau kognitif merupakan domain yang sangat penting dalam membentuk tindakan seseorang (overt behavior). Seseorang yang tidak mempunyai pengetahuan akan berakibat tidak mempunyai landasan dalam bertindak, karena perilaku yang didasari oleh pengetahuan akan lebih langgeng dari pada perilaku yang tidak didasari oleh pengetahuan.

Peningkatan pengetahuan dapat dilakukan dengan peningkatan pendidikan, pelatihan, health education, dan informasi melalui media massa dan elektronik. Health education yang dilakukan dengan penyebaran pesan dan menanamkan keyakinan akan membuat ibu tidak saja sadar, tahu, dan mengerti, tetapi juga mau dan bisa melakukan suatu anjuran yang ada hubungannya dengan kesehatan (Machfoedz, dkk. 2005). Sehingga health education meningkatkan pengetahuan dan kemampuan ibu dalam merawat BBLR. Akibat jika pengetahuan ibu tentang perawatan BBLR rendah, maka bayi akan mengalami hipotermia, gangguan pola nafas, gangguan nutrisi, infeksi dan kematian.

Health education di rumah sakit (Promosi Kesehatan di Rumah Sakit atau PKRS) berusaha mengembangkan pengertian menggugah kesadaran dan minat pasien pasien, keluarga dan pengunjung, dalam penyembuhan dan pencegahan penyakit (Kemenkes, 2011). Salah satu cara untuk meningkatkan pengetahuan seseorang adalah melalui pendidikan kesehatan atau health education yang merupakan upaya memberikan informasi kesehatan yang 
menambah landasan pengetahuan sehingga akan memudahkan terjadinya tindakan (Notoatmodjo, 2003).

Health education kepada ibu bayi tentang perawatan BBLR diharapkan dapat diterapkan saat bayi sudah dibawa pulang. Kegiatan Health education berupa penyuluhan merupakan salah satu tugas perawat sebagai pendidik yaitu memberikan promosi kesehatan kepada ibu dengan BBLR. Health education yang dilakukan perawat akan meningkatkan pengetahuan ibu dalam perawatan BBLR, sehingga akan membantu meningkatkan kualitas hidup BBLR.

Berdasarkan uraian diatas, peneliti tertarik meneliti pengaruh health education terhadap pengetahuan ibu tentang perawatan Bayi Berat Lahir Rendah di Ruang Teratai RSUD Dr.Harjono Ponorogo.

\section{METODE PENELITIAN}

Desain pada penelitian ini yaitu pre-eksperiment dengan pendekatan rancangan One Group Pretest-Postest dalam rancangan ini tidak ada kelompok pembanding (kontrol), tetapi paling tidak sudah dilakukan observasi pertama (Pretest) yang memungkinkan peneliti dapat menguji perubahan-perubahan yang terjadi setelah adanya eksperimen atau perlakuan (Notoatmodjo, 2010). Desain ini untuk mengetahui pengaruh Health Education Terhadap Pengetahuan Ibu Tentang Perawatan Bayi Berat Lahir Rendah Di Ruang Teratai RSUD Dr. Harjono Ponorogo.

Pada penelitian ini populasinya adalah seluruh ibu dengan Bayi Berat Lahir Rendah di ruang Teratai RSUD Dr. Harjono Ponorogo periode 1-31 Desember sejumlah 37 orang.

Metode pengambilan sampel yang digunakan accidental sampling yaitu penentuan sampel berdasarkan kebetulan, yaitu siapa saja bertemu dengan peneliti dan sesuai dengan kriteria sampel yang diinginkan peneliti (Sugiyono, 2007).

Uji statistik menggunakan Wilcoxon Signed-Rank Test melalui program SPSS versi 20 dengan $\alpha=0,05$ $(5 \%)$.

\section{HASIL PENELITIAN}

1. Pengetahuan Ibu tentang Perawatan BBLR sebelum dilakukan health education

Tabel 1.

Distribusi frekuensi Pengetahuan Ibu tentang Perawatan BBLR di Ruang Teratai RSUD Dr. Harjono Ponorogo sebelum dilakukan health education

Desember 2019

\begin{tabular}{cccc}
\hline No & $\begin{array}{c}\text { Pengetahua } \\
\mathrm{n}\end{array}$ & Frekuensi & $(\%)$ \\
\hline 1 & Kurang & 12 & 38,7 \\
\hline 2 & Cukup & 16 & 51,6 \\
\hline 3 & Baik & 3 & 9,7 \\
\hline & Jumlah & 31 & 100,0 \\
\hline
\end{tabular}

Berdasarkan tabel diatas dari 31 responden didapatkan sebagian besar yaitu 16 responden $(51,6 \%)$ pengetahuan cukup

2. Pengetahuan Ibu tentang Perawatan BBLR setelah dilakukan health education

Tabel 2

Distribusi frekuensi Pengetahuan Ibu tentang Perawatan BBLR di Ruang Teratai RSUD Dr. Harjono Ponorogo sesudah dilakukan health education

Desember 2019

\begin{tabular}{|c|c|c|c|}
\hline No & $\begin{array}{c}\text { Pengetahua } \\
n\end{array}$ & $\begin{array}{c}\text { Frekuens } \\
\text { i }\end{array}$ & $(\%)$ \\
\hline 1 & Kurang & 2 & 6,5 \\
\hline 2 & Cukup & 11 & 35,5 \\
\hline 3 & Baik & 18 & 58,1 \\
\hline & Jumlah & 31 & $\begin{array}{c}100, \\
0\end{array}$ \\
\hline
\end{tabular}

Berdasarkan tabel diatas dari 31 responden didapatkan sebagian besar 
yaitu 18 responden

$(58,1 \%)$ pengetahuan baik.

3. Pengaruh health education terhadap Pengetahuan Ibu tentang Perawatan Bayi Berat Lahir Rendah di Ruang Teratai RSUD Dr. Harjono Ponorogo Tabel 3

Tabulasi silang pengaruh health education terhadap Pengetahuan Ibu tentang Perawatan BBLR di Ruang Teratai RSUD Dr. Harjono Ponorogo Desember 2018

\begin{tabular}{|c|c|c|c|c|}
\hline Pengetahua & \multicolumn{3}{|c|}{ Sesudah } & \multirow[t]{2}{*}{$\mathrm{Jml}$} \\
\hline Sebelum & K & $\mathrm{C}$ & B & \\
\hline Kurang & 2 & 8 & 2 & 12 \\
\hline Cukup & 0 & 3 & 13 & 16 \\
\hline Baik & 0 & 0 & 3 & 3 \\
\hline Jumlah & 2 & 11 & 18 & 31 \\
\hline \multicolumn{5}{|c|}{$\begin{array}{l}\text { didapatkan hampir setengahnya yaitu } \\
13 \text { responden }(41,9 \%) \text { sebelum } \\
\text { dilakukan health education pengetahuan } \\
\text { cukup dan setelah dilakukan health } \\
\text { education tentang pengetahuan baik. }\end{array}$} \\
\hline
\end{tabular}

\begin{tabular}{cr}
\hline & POST - PRE \\
\hline Z & $-4,630(a)$ \\
$\begin{array}{c}\text { Asymp. Sig. (2- } \\
\text { tailed) }\end{array}$ &, 000 \\
\hline Out put & SPSS, pada taraf
\end{tabular}
kepercayaan $95 \% \quad(\alpha=0,05), \quad p$-value atau Sig. (2-tailed) pada tabel wilcoxon signed ranks test adalah 0,000 , angka ini lebih kecil dari $\alpha=0.05 \quad(0,000 \leq 0,05)$ yang artinya ada Pengaruh health education terhadap Pengetahuan Ibu tentang Perawatan Bayi Berat Lahir Rendah di Ruang Teratai RSUD Dr. Harjono Ponorogo.

\section{PEMBAHASAN}

Berdasarkan tabulasi silang didapatkan hampir setengahnya yaitu 13 responden (41,9\%) sebelum dilakukan health education pengetahuan cukup dan setelah dilakukan health education tentang pengetahuan baik. Out put SPSS, pada taraf kepercayaan
95\% $(\alpha=0,05), \quad p$-value atau Sig. (2tailed) pada tabel wilcoxon signed ranks test adalah 0,000 , angka ini lebih kecil dari $\alpha=0.05(0,000 \leq 0,05)$ yang artinya ada Pengaruh health education terhadap Pengetahuan Ibu tentang Perawatan Bayi Berat Lahir Rendah di Ruang Teratai RSUD Dr. Harjono Ponorogo.

Manusia mempunyai dorongan dasar ingin mengetahui, untuk mencari penalaran, dan untuk mengorganisasikan pengalamannya. Pemberian informasi adalah pembelajaran kepada masyarakat agar mau melakukan tindakan-tindakan untuk memelihara, dan mengatasi masalah-masalahnya. Perubahan atau peningkatan kesehatan dihasilkan oleh pemberian informasi didasarkan kepada pengetahuan dan kesadarannya melalui proses pembelajaran (Notoatmodjo, 2003).

BBLR memiliki resiko yang lebih tinggi untuk terkena depresi,hiperaktif, obesitas, hipertensi, diabetes dan gagal jantung sehingga membutuhkan biaya perawatan yang tinggi (Lulakamal, 2016). Perawatan BBLR adalah usaha yang dilakukan oleh tenaga kesehatan, ibu bayi dan keluarga dalam rangka mempertahankan kelangsungan hidup BBLR (Sayekti, 2015). Orang tua harus mempunyai kemauan yang keras dan mengetahui perawatan BBLR karena setelah pulang dari tempat melahirkan bayi akan dirawat oleh orang tua. Perawatan BBLR yang baik dan benar akan meningkatkan kualitas hidup BBLR sehingga terhindar dari resiko gangguan pertumbuhan dan perkembangan maupun kematian (Judarwanto, 2009).

Seseorang yang tidak mempunyai pengetahuan akan berakibat tidak mempunyai landasan dalam bertindak, karena perilaku yang didasari oleh pengetahuan akan lebih langgeng dari pada perilaku yang tidak didasari oleh pengetahuan. Peningkatan pengetahuan dapat dilakukan dengan peningkatan pendidikan, pelatihan, health education, 
dan informasi melalui media massa dan elektronik. Health education yang dilakukan dengan penyebaran pesan dan menanamkan keyakinan akan membuat ibu tidak saja sadar, tahu, dan mengerti, tetapi juga mau dan bisa melakukan suatu anjuran yang ada hubungannya dengan kesehatan (Machfoedz,dkk.2012).

Kegiatan health education meningkatkan pengetahuan dan kemampuan ibu dalam merawat BBLR, jika pengetahuan ibu tentang perawatan BBLR baik, maka bayi tidak akan mengalami hipotermia, tidak terjadi gangguan pola nafas, tidak masalah dengan pemenuhan nutrisi, tidak terjadi infeksi dan menurunkan resiko kematian.

\section{KESIMPULAN}

Berdasarkan hasil penelitian dan tujuan khusus yang telah ditetapkan, maka kesimpulan yaitu:

1. Pengetahuan Ibu tentang Perawatan Bayi Berat Lahir Rendah di Ruang Teratai RSUD Dr. Harjono Ponorogo sebelum dilakukan health education sebagian besar yaitu 16 responden $(51,6 \%)$ cukup.

2. Pengetahuan Ibu tentang Perawatan Bayi Berat Lahir Rendah di Ruang Teratai RSUD Dr. Harjono Ponorogo setelah dilakukan health education sebagian besar yaitu 18 responden $(58,1 \%)$ pengetahuan baik.

3. Ada pengaruh health education terhadap pengetahuan ibu tentang perawatan Bayi Berat Lahir Rendah di Ruang Teratai RSUD Dr.Harjono Ponorogo $p$ value $0,000 \leq \alpha 0,05$.

\section{SARAN}

Berdasarkan kesimpulan maka saran dalam hasil penelitian ini adalah:

1. RSUD Dr. Harjono PonorogO

Peningkatan kegiatan health education pada semua ibu Bayi Berat Lahir Rendah Rendah pada hari kedua post partum sehingga ibu bayi mempunyai pengetahuan dan ketrampilan saat merawat bayinya.

2. Profesi perawatan

Salah satu tugas perawat yaitu sebagai educator, maka perawat harus melakukan health education secara rutin selama pemberian asuhan keperawatan. Penyuluhan dapat dilakukan secara individu atau berkelompok, perawat langsung mendemonstrasikan perawatan BBLR dan ibu bayi diminta untuk mempraktekkan perawatan BBLR dengan didampingi perawat.

3. Responden

Ibu bayi hendaknya meningkatkan pengetahuan tentang perawatan BBLR melalui petugas kesehatan, media massa atau majalah. Pada saat bertemu dengan perawat, ibu bayi dapat menanyakan secara langsung tentang perawatan bayi BBLR selama dirumah.

4. Peneliti selanjutnya

Penelitian ini dapat dikembangkan dengan menganalisis hubungan pengetahuan dengan tindakan ibu dalam merawat BBLR.

\section{DAFTAR PUSTAKA}

Arikunto. (2010). Prosedur Penelitian Suatu Pendekatan Praktik. Jakarta : Rineka Cipta

Asiring. (2003).Perawatan Bayi Resiko Tinggi. Jakarta: EGC

Asmadi. (2008). Konsep Dasar Keperawatan, Jakarta : EGC

Hastono, P.S. (2006) Basic Data Analysis for Health Research. Fakultas Kesehatan Masyarakat, Jakarta : Universitas Indonesia

Hidayat, A.A. (2011). Riset Keperawatan dan Teknik Penulisan Ilmiah. Jakarta: Salemba Medika

Judarwanto pediatrician (2009). BBLR, Waspadai Resikonya. Didapat dari

https://prematureclinic.wordpres 
s. Diakses tanggal 27 April 2016 Jam 21.11 WIB

Kemenkes. (2011). Standar Promosi Kesehatan Rumah Sakit

Lulakamal. (2016). Dampak BBLR pada tumbuh kembang dan kehidupan selanjutnya

Machfoedz, I. (2009). Statistik Deskriptif. Yogyakarta: Fitramaya

Machfoedz, Suryani, Sutrisno, Santosa. (2005). Pendidikan Kesehatan bagian dari Promosi Kesehatan. Yogyakarta: Fitramaya.

Maharani. (2014). Perawatan BBLR. Bali. Ikatan Dokter Anak Indonesia

Notoatmodjo. (2013). Pendidikan dan Perilaku Kesehatan. Jakarta. Rineka Cipta.

Kesehatan Teori dan Aplikasi.
Jakarta. Rineka Cipta
- --. (2010). Metodologi

penelitian kesehatan . Jakarta. PT

$$
\text { Rineka Cipta }
$$

Nursalam. (2016). Konsep Dan Penerapan Metodologi Penelitian Ilmu Keperawatan. Jakarta: EGC.
Proverawati, I. (2010). Berat Badan Lahir Rendah (BBLR). Yogyakarta: Nuha Medika

Riskesdas. (2013). Riset Kesehatan dasar, Badan Penelitian dan Pengembangan Kesehatan, Kementerian Kesehatan RI. 2013

Roeslani. D. (2016). Perawatan BBLR. didapat http://www.library.usu.ac.id/arti cle,_diakses tanggal 17 Mei 2018 Jam 16.04 WIB

Sayekti. (2015). Tatalaksana Bayi Berat Badan lahir Rendah. Didapat dari http://www.smallcrab.com. Diakses 18 Mei 2018 jam 09.07 WIB

Sudarti, A.F. (2012), Asuhan Kebidanana, Neonatus, Bayi, dan Anak Balita.Yogyakarta: Nuha Medika

Sugiyono. (2007). Statistik untuk Penelitian. Bandung : Alfabeta

Suparyanto, (2011). Toksonomi Bloom, didapat http://www, pengetahuan masyarakat.html. Diakses tanggal 3 Juli 2018 Jam 17.00 WIB.

Susilo.R. (2011). Pendidikan Kesehatan dalam keperawatan. Yogyakarta: Nuha Medika 